The curricular model of personal development and the multimodal text in the context of new curricula for Romanian language and literature. Diachronic and synchronic perspective

Monica Halaszi, Mușata Bocoș 


\title{
The curricular model of personal development and the multimodal text in the context of new curricula for Romanian language and literature. Diachronic and synchronic perspective
}

\author{
Monica Halaszi ${ }^{a^{*}}$, Mușata Bocoș ${ }^{b}$ \\ aDoctoral School"Educational, Reflection, Development", Faculty of Psychology and Educational Sciences, Babeș-Bolyai University Cluj-Napoca, \\ Romania, 7 Sindicatelor Street, 400029, Romania \\ ${ }^{b}$ Babeş-Bolyai University, Faculty of Psychology and Educational Sciences, Babeș-Bolyai University Cluj-Napoca, 7 Sindicatelor Street, 400029, \\ Romania \\ *Corresponding author: monica.halaszi@gmail.com
}

\section{Abstract}

\section{Keywords:}

competences, curricular paradigm, the model of personal development, multimodal text, Romanian language and literature curriculum

\section{Zusammenfasung}

Schlüsselworte:

Kompetenzen, Lehrplanparadigma, Modell der persönlichen Entwicklung, multimodaler Text, Lehrplan für rumänische Sprache und Literatur
The new pedagogies have forced a rethinking of the educational system, including the curriculum. The curricular model of personal development, dominant in the school curricula applied in the gymnasium, shifts the focus to the student, favors active-participatory methods and favors reflection on oneself, on others and on the world. Although there is more talk now about this curricular model, it is recurrent in visions of education from Aristotle to Dewey, being explicitly found in Bain's vision of "exceptional learning". The inclusion of the multimodal text in the Romanian language and literature curriculum for the gymnasium, built on the curricular model of personal development, is justified precisely because it stimulates selfknowledge, understanding of the world and creativity. Although the concept of multimodal text is present in the school curriculum, including at the level of competences, textbooks do not pay much attention to it.
The new pedagogies require a rethinking of the educational system, a rebalancing of the structural and functional components of education, including the curriculum, understood broadly as a whole of the educational processes and learning experiences of a student during his schooling, and narrowly as a whole regulatory document that generate these processes.

The National Education Law no. 1/2011 generated two essential changes in the Romanian education system: the introduction of the preparatory class and the orientation of the curriculum towards the formation of key competencies, their structuring level being visible in the graduate profile, a document that establishes the status of the educable at the end of each schooling. A consequence in the operational perspective (Bocoș \& Jucan, 2019) of this curricular reform was the elaboration of new framework plans, new school curricula and new alternative, digital textbooks. 


\section{The curricular model of personal development. Not such a new model}

Firstly, the program is characterized by reconfiguring the previously applied curricular model. The dominant curricular model of personal development (Sâmihăian, 2014; Pamfil, 2016), which does not cancel the communicative-functional model, but diminishes its weight, has as a starting point the pedagogical reform of the first decades of the twentieth century, a Copernican revolution (Dewey, 1929) focused on the idea that in the elaboration of educational goals one should not start from the contents, but from the needs of the educable, from his learning potential. However, the perspective is not so new, it is found over time in the theses of some philosophers and pedagogues belonging to different temporal and spatial contexts. For example, in Aristotle's vision, formulated in Politics, education is related to the need for happiness of the individual, and not only to the needs and reasons of the state. Happiness (eudaimonia) is understood as the state of man acting in accordance with his own nature, which requires the creation of contexts for man to reach the stage that allows him to know the characteristics of his own person. A few centuries later, Rabelais amends in his novels the pedagogical principles of the scholastic type, promoting the advantages of humanistic pedagogy, at the center of which is the human being and its harmonious development. And the pedagogical system developed by Comenius takes into account the personal development of the child, relying on an authentic and thorough education, consistent and intuitive.

The model of conformity with the nature and axiomatics of universal education contain some of the principles of the model of personal development, according to which learning is generated by investigating and exploring the world and not by transmitting information, much less unnecessary information. Education is seen as an active process, developer of lateral thinking, the human being not having enough understanding of the world, in the conditions in which it must be able to participate in its change, through active citizenship: All must be trained not to enter the world as mere spectators, but as future people of action. Jean-Jaques Rousseau's vision of education is similar to that of Comenius, in the sense that it starts from conformity with nature, but, unlike its predecessor, in building its own set of principles takes into account the concrete nature of the child. In Emile or about education, Rousseau promotes the need for free development of the child and the importance of capitalizing on his experiences, and when discussing the orientation towards intellectual and moral education or the relationship between desire and necessity, the French philosopher only anticipates the model of personal development. In fact, the human condition, which he considers a vocation of humanity, concentrates the central function of education to determine human development in its essence, which involves not only knowledge of the world and self-knowledge, but also the ability to relate creatively to concrete situations. And some of Kantian Herbart's pedagogical ideas converge on this vision. From his point of view, education is not an end in itself, but a way for the formation of the moral man, and between this ideal and the moment when education begins there are intermediate goals, generated by the interests of students, be they empirical, speculative, aesthetic, moral, social or religious. His conclusion is that the school has the role to develop multilateral receptivity to the student and to cultivate multilateral interest, the effect being visible in the way the future adult will relate to himself, to others and to the world in which he will live.

The twentieth century was decisive for changing the paradigm of education. Criticizing the conservative view that the school's purpose is to convey information, Dewey proposes a life-related education that meets the child's (autotelic) developmental needs. Although he does not call it that, the curricular model he proposes is close to that of personal development, Dewey pointing out that the learning process belongs to the child, whose potential must be allowed to assert itself and practice. Contemporaneous with Dewey, Bobbitt, a follower of social efficiency in education, also associates the curriculum with learning experiences, emphasizing that capitalizing on experiences contributes to ensuring the ability to understand the world and oneself.

In the model of personal development that articulates the current curriculum, we started from Bain's (2004) vision of exceptional learning. In the approach taken to define this concept, Bain establishes that this type of learning presupposes a double direction of the didactic approach: towards the intellectual development and towards the personal development of the student. If intellectual development is focused on cognitive processes, the accumulation of content, the structuring of the competence to learn to learn, but also on metacognition, personal development involves understanding the self - emotions and feelings, limits, prejudices and personal abilities - and what it means to be human, the manifestation of responsibility to oneself and to others, of empathy, and last but not least, moral development.

\section{The curricular model of personal development in the Romanian language and literature curriculum for the gymnasium}

The school programs for secondary education, the discipline of Romanian language and literature, implemented starting with the school year 2017 - 2018, therefore propose a new curricular vision, new skills and contents. Elements specific to the curricular model of personal development are also found in the Romanian language and literature programs from the first decades of 
the 19th century, but disappear in the analytical programs from 1947 to 1953 , in the context of excessive ideologization of the discipline. followed by valuing only the aesthetic dimension of literary texts, without producing changes in the finalities. The program of 1908, more oriented towards the model of personal development than the ones that will follow, includes as finality of the Romanian language and literature discipline in the gymnasium the development of students' judgment and feeling and of all their soul powers, thus aiming at the affective dimension of the human psyche. novelty of the program being the emphasis on encouraging the expression of emotional reactions to the text (for the reading subdomain).

Gradually, in the subsequent programs, from 1929 and 1935, the tendency to technicalize the discipline becomes obvious, and the references to its affective valences are not explicit. The reform of education in the years following the Second World War, materialized by the school curriculum of 1947, reoriented the study of the discipline to the principles of communist ideology, to be fully subordinated to the Soviet model between 1950 - 1956. All subsequent programs will emphasize the canon, the stylistic and structural analysis, the ideological, social and political dimension of the literary text, nullifying any possibility of reflection on it.

The first school curricula that will impose a new vision on the discipline and a new curricular model, communicative-functional, appear in 1998, among their aims being the training of a young person able to understand the world around him, to communicate and interact with peers., to be effectively integrated in the context of the future school and professional path. Placing the student at the center of activities aimed at developing communication skills in Romanian and cultural awareness and expression of students, their cognitive and emotional dimension, the new program for Romanian language and literature for high school (2017) imposes the model of personal development in the study of discipline, privileging reflection on interpersonal and intercultural relations. The text becomes an instrument of knowing the world and the self, in its exploration capitalizing on the student's personal experiences and stimulating critical thinking and reflection, which leads to in-depth learning (Chiş, 2005). Therefore, the curricular model of personal development has as specific the recalibration of the relationship between the student as object (beneficiary of educational influences) and subject (active participant) of education (Ionescu\& Bocoș, coord., 2017) and curriculum and emphasizes the student's personal, social, cultural and academic benefits: setting up one's own set of values, a deeper knowledge of oneself and others, of the world in which one lives, the development of creativity, the use of language acquisitions to communicate appropriately to the context.

\section{Multimodal text. The presence of the multimodal} text in the programs and textbooks for the Romanian language and literature discipline, gymnasium level

The adoption of the curricular model of personal development required the introduction of new concepts in the field of reading, less theorized in the Romanian educational space, such as a new classification of texts in terms of their format - continuous, discontinuous and multimodal.

The multimodal text is a concept adopted in the Romanian didactic space recently, with the initiation in 2013 of the Reading as a life skill Contest, but the term was coined by Kress and van Leeuwen as far back as 1996. In their view, any text whose meanings materialize through more than one semiotic code is a multimodal one, thus integrating the various textual forms generating meanings, and involves the combination of two or more semiotic systems in the series: linguistic, visual, audio, gestural, spatial This basic feature justifies the multitude multimodal text typologies, which can be identified in visual design, photographs, magazines, books in electronic format, web pages, film product, ballet show, etc.

Although, like any text, it supports two types of reading - efferent, the reader's interest focusing on the information transmitted by the text and how he can use it, and aesthetic, the reader being interested in what he thinks and feels during reading - the multimodal text requires a different approach, taking into account not only the linguistic system but also the other semiotic systems: visual (which involves the analysis of color, shape, style, size or perspective), gestural (observation of facial expressions, body language), spatial (positioning, proximity or distance between objects), auditory (melodic line, sound effects, ambient noise, silence, intonation or volume). The decryption of the multimodal therefore denotes both the linguistic and communicative abilities of the students, as well as their thinking and imaginative abilities and stimulates selfknowledge. understanding the world and creativity.

An analysis of the Romanian language and literature program mentioned above, made by us in Table 1, from the perspective of this concept, revealed that the multimodal is found five times in specific skills, the multimodal text being explicitly associated with the ability to receive the text.

Table 1. The term multimodal text in school curricula for Romanian language and literature, middle school level (2017)

\begin{tabular}{|c|c|c|}
\hline $\begin{array}{c}\text { General } \\
\text { competence }\end{array}$ & Grade & Specific competence \\
\hline $\begin{array}{l}\text { 1. Participating in } \\
\text { verbal interactions } \\
\text { in rarious } \\
\text { communication }\end{array}$ & 8th & $\begin{array}{l}\text { 1.3. Making a } \\
\text { multimodal oral } \\
\text { presentation in front of an } \\
\text { audience, correlating the }\end{array}$ \\
\hline
\end{tabular}




\begin{tabular}{lll}
\hline situations & by & verbal, paraverbal and \\
receiving & and & nonverbal elements in some \\
producing & the oral & argumentation strategies
\end{tabular}
text

\section{Receiving} written text of various types

5 th

2.1. Identify important information from literary and non-literary texts, continuous, discontinuous and multimodal

6th 2.1. Correlation of explicit and implicit information from literary and non-literary texts, continuous, discontinuous and multimodal

7th 2.1. Recognition of the ways in which information is organized from literary and non-literary texts, continuous, discontinuous and multimodal texts

8th 2.1. Evaluation of information and communication intentions from literary, non-literary, continuous, discontinuous and multimodal texts
The term appears only once in the list of contents, in the syllabus for the 5th grade: Narrative in multimodal texts (text and image - comics), while being present in the sequence containing text suggestions: multimodal texts: textbook, comics (5th grade), multimodal texts (6th grade), multimodal texts: texts from illustrated encyclopedias, on paper or online (7th grade), multimodal texts: advertisements (8th grade). It is also included in the suggestions for learning activities that accompany competence 5.2. The analysis of common elements identified in one's own culture and in the culture of other peoples (sixth grade): the selection and processing of information from various materials (oral, written, multimodal), presenting the values promoted in the traditions and customs of different cultures. In the chapter Methodological suggestions, in detailing the aspects related to competence 3 (Writing written text of various types) it is specified that the production of various multimodal texts is one of the capabilities covered by the program.

The textbooks for the Romanian language and literature discipline, gymnasium level, include the multimodal text in their content. If each of the textbooks for 5 th grade proposes learning activities for the content Narrative in multimodal texts (text and image - comics), those for grades 6 - 8 do not give equal importance to multimodal, as can be seen in table 2 (own conception).

Table 2. The multimodal text in school textbooks for gymnasium, Romanian language and literature discipline

\begin{tabular}{|c|c|c|c|}
\hline Grade & $\begin{array}{l}\text { Publishing } \\
\text { house }\end{array}$ & Lesson title & Remarks \\
\hline \multirow[t]{12}{*}{5 th } & Aramis & $\begin{array}{l}\text { Multimodal text. Comic } \\
\text { book }\end{array}$ & $\begin{array}{l}\text { The comic is based on an excerpt from the novel The Wizard of } \\
O z \text { by Frank Baum }\end{array}$ \\
\hline & Ars Libri & $\begin{array}{l}\text { Narrative in multimodal } \\
\text { texts (text and image - } \\
\text { comics) }\end{array}$ & $\begin{array}{l}\text { Three vignettes from a comic strip that capture events specific } \\
\text { to the school context }\end{array}$ \\
\hline & Art & Multimodal text & $\begin{array}{l}\text { The comic made after an excerpt from the novel The Lightning } \\
\text { Thief by Rick Riordan }\end{array}$ \\
\hline & Booklet & $\begin{array}{l}\text { Multimodal text. Comic } \\
\text { book }\end{array}$ & $\begin{array}{l}\text { The comic is based on an excerpt from the novel The } \\
\text { Adventures of Tom Sawyer by Mark Twain }\end{array}$ \\
\hline & CD Press & Comic book & Comic book entitled Journey with adventures \\
\hline & Corint & $\begin{array}{l}\text { The narrative in } \\
\text { multimodal texts }\end{array}$ & Comic book that captures events specific to the school context \\
\hline & EDP & - & Excerpt from the comic Greuceanu and the beacon of the eartl \\
\hline & Intuitext & Comic book & $\begin{array}{l}\text { George and the secret key to the universe, after Lucy and } \\
\text { Stephen Hawking }\end{array}$ \\
\hline & Intuitext & $\begin{array}{l}\text { Text and image. School } \\
\text { textbook }\end{array}$ & Excerpt from a geography textbook \\
\hline & Litera & $\begin{array}{l}\text { Narrative text in images } \\
\text { and words. Comic book }\end{array}$ & $\begin{array}{l}\text { Excerpt from the illustration of the novel Around the Earth in } \\
\text { Eighty Days by Jules Verne }\end{array}$ \\
\hline & Paralela 45 & $\begin{array}{l}\text { Narration in text and } \\
\text { images }\end{array}$ & $\begin{array}{l}\text { Excerpt from the comic The mighty Prâslea and the golden } \\
\text { apples }\end{array}$ \\
\hline & Sigma & The narrative in & Illustrations for The Book with Apollodorus by Gellu Naum \\
\hline
\end{tabular}


6th EDP (Cârstea, Literary text and film

Avram, Sanda,

Dragomirescu)

EDP (Norel,

Bucurenciu,

Dragu)

7th Aramis

Art-Klett Multimodal text (update).

Encyclopedia

Intuitext

8th Aramis

Art-Klett

Corint
Nonliterary text.

Multimodal text. The

commercial

From reading the text to reading the image. The commercial
Unit 6 (The artistic world) proposes the approach of two screenings of the novels The Jderi Brothers by Mihail Sadoveanu and the Castle of the Carpathians by Jules Verne. There are no lessons for studying the multimodal text.

There are no lessons for studying the multimodal text Illustrated encyclopedia article. Wikipedia, The Runc secular forest

There no lessons for studying the multimodal text.

There are no lessons for studying the multimodal text.

Advertising for engine oil

Promoting a theater show
Despite the uneven and inconsistent attitude of authors towards the multimodal text, it should be borne in mind that the textbook itself is limited to this type of text, its use allowing the structuring of the competence to identify important information from literary and non-literary texts, continuous, discontinuous and multimodal.

\section{Conclusions}

The use of multimodality, both in reception and text production activities, is in accordance with the curricular model of development proposed by the current Romanian language and literature program for high school, facilitating the development of multimodal competence (Lebrun, 2012) and learning integrated (Ciolan, 2008), stimulating the creative and experimental language, so necessary in a world dominated by technology, image and media culture.

Authors note: The authors have equal contributions to this article.

Monica Halaszi teaches Romanian language and literature at the Liviu Rebreanu National College in Bistrița and is currently a doctoral student at Babeș-Bolyai University. She was a school inspector of Romanian language and literature for 2 years, and currently has the status of collaborator of the Center for Independent Journalism. Her research interests are oriented towards the didactics of reading and of the comprehension of multimodal texts. She is also concerned with the means by which non-formal education can intermingle, in the instructional educational process, with formal education and has experience in developing school curricula and textbooks.

Muşata Bocoș is University Professor and Ph.D. Coordinator at the Faculty of Psychology and Sciences of Education (Babeș-Bolyai University, Cluj-Napoca,
Romania). She has obtained a Ph.D. in Educational Sciences in 1997 at Babeș-Bolyai University. Her research interests are reflected in a series of studies and articles published in important national and international journals. Her teaching activity covers several domains such as the theory and methodology of curriculum, general didactics, and educational research.

\section{References}

Anstey, M., Bull, G. (2018). Foundations of multiliteracies. Reading, Writing and Talking in the 21st Century (2018). New York: Routledge.

Bain, K. (2004). What the Best College Teachers Do. Cambridge, London: Harvard University Press.

Bobbitt, F. (1971). The Curriculum. New York: Arno Press. Bocoș, M., Jucan, D. (2019). Fundamentele pedagogiei. Teoria şi metodologia curriculumului. Repere şi instrumente didactice pentru formarea profesorilor. Pitești: Editura Paralela 45.

Bocoș, M., Răduț-Taciu, R. Stan, C. (2018). Dicţionar praxiologic de pedagogie. Volumul IV: M-O.Piteşti: Editura Cartea Românească Educațional.

Chiş, V. (2005). Pedagogia contemporană. Pedagogia pentru competenţe. Cluj-Napoca: Editura Casa Cărţii de Ştiinţă.

Ciolan, L. (2008). Invățtarea integrată. Fundamente pentru un curriculum transdisciplinar. Iași: Editura Polirom.

Comenius, J. A. (1970). Didactica Magna. București: Editura Didactică şi Pedagogică.

Dewey, J. (1977). „Copilul și curriculumul”.În Trei scrieri despre educație. București: Editura Didactică și Pedagogică.

Dewey, J. (2008), The Quest for Certainty: A Study of the Relation of Knowledge and Action. In The Later Works of John Dewey, Volume 4. Carbondale: Board of Trustees, Southern Illinois University. 
Herbart, J.Fr. (1976). Prelegeri pedagogice. București: Editura Didactică și Pedagogică.

Ionescu, M., Bocoș, M. (coord.) (2017). Tratat de didactică modernă. Pitești: Editura Paralela 45.

Iuga, N. (2015), Din istoria marilor idei etice și psihologice. Cluj-Napoca: Editura Grinta.

Kress, G., van Leeuwen, T. (2006). Reading Images. The Grammar of Visual Design. New York: Routledge.

Lebrun, M., Lacelle, N., Boutin, J. F. (2012). La littératie médiatique multimodale. Québec: Press de l'Université du Québec.

Pamfil A., Tămâian, I. (2005). Studiul limbii și literaturii române în secolul XX. Paradigme didactice. ClujNapoca: Casa Cărții de Știință.

Pamfil, A. (2016). Didactica literaturii. Reorientări. București: Editura Art.

Rabelais, F. (1989), Gargantua\&Pantagruel. București: Editura Ion Creangă.

Rousseau, J. J. (1978). Emil sau despre educatie. București: Editura Didactică și Pedagogică.
Rouvière, N. (coord.) (2012). Bande dessinée et enseignement des humanités. Grenoble: ELLUG.

Sâmihăian, F. (2014). O didactică a limbii și literaturii române. Provocări actuale pentru profesor și elev. București: Editura Art.

*** Ministerul Cultelor și Instrucțiunei Publice (1908). Programa analitică a învățământului secundar. București.

*** Ministerul Educaţiei Naţionale, Consiliul Naţional Pentru Curriculum (1998). Curriculum Naţional pentru invăţământul obligatoriu. Cadru de referinţă. București.

*** Ministerul Educației Naționale. (2017). Programa școlară pentru disciplina limba și literature română. Clasele a V-a - a VIII-a. Available at: http://programe.ise.ro/Portals/1/Curriculum/2017progr/01-

Llimba\%20si\%20literatura\%20\%20romana\%20matern a.pdf (Accessed at 17.09.2020). 